JOANNA SIKORSKA

Wydział Filologii Polskiej i Klasycznej

Uniwersytet im. Adama Mickiewicza w Poznaniu
Images

vol. XXI/no. 30

Poznań 2017

ISSN 1731-45OX

\title{
Między realnościa a wirtualnością. Wykorzystanie fotogrametrii w grze wideo Zaginięcie Ethana Cartera
}

\begin{abstract}
Aвstract. Sikorska Joanna, Między realnością a wirtualnością. Wykorzystanie fotogrametrii $w$ grze wideo Zaginięcie Ethana Cartera [From reality to virtuality: the use of photogrammetry in the video game The Vanishing of Ethan Carter]. „Images” vol. XXI, no. 30. Poznań 2017. Adam Mickiewicz University Press. Pp. 165-175. ISSN 1731-450X. DOI 10.14746/i.2017.12.

Today we are seeing significant technological progress in the context of imitating reality. One technology which emulates our reality in comprehensive way is photogrammetry. The aim of the article is to illustrate the using of photogrammetry in the context of video games. The main part of the text is an analysis of The Vanishing of Ethan Carter (The Astronauts, 2015). The authors of this video game decided to apply photogrammetry in order to display vast spaces in which an avatar is moving. I indicate that such an implementation not only creates a reliable illusion of reality, but also crucially affects video games' poetics and narration.
\end{abstract}

KEYWORDS: photogrammetry, video games, digital games, immersion, poetics of video games, reality, virtuality, virtual reality, digital technology, The Vanishing of Ethan Carter, The Astronauts

Koncepcja precesji symulakrów Jeana Baudrillarda, zaproponowana w eseju pod tym samym tytułem i wyrażająca przekonanie o zmianie paradygmatu istnienia rzeczywistości, wskazuje na istotną konsekwencję rozpowszechniania się technologii nowomedialnej rozwój wirtualnych światów[1]. Chociaż idea sztucznej rzeczywistości znana była na długo przed powstaniem mediów cyfrowych, to spopularyzowała się wraz z ich nadejściem. Jak wskazują Grigore C. Burdea oraz Philippe Coiffet w pozycji Virtual Reality Technology, wynika to z faktu, iż nowoczesna technologia spełnia trzy najistotniejsze warunki, umożliwiające powstanie wirtualnych przedstawień. Autorzy określają je mianem trzech „I”; są to: immersja (immersion), interakcja (interaction) oraz wyobraźnia (imagination) [2] . Twierdzą, iż cyfrowa realność jest symulacją, w której grafika komputerowa zostaje wykorzystana do stworzenia realistycznie wyglądającej rzeczywistości. Użytkownik może $\mathrm{w}$ chodzić $\mathrm{z}$ nią $\mathrm{w}$ interakcję, a to $\mathrm{z}$ kolei pobudza jego wyobraźnię. $\mathrm{W}$ tym kontekście sformułowanie imagination rozumiane jest jako

[1] W niniejszym artykule korzystam naprzemiennie z nazw: „wirtualna rzeczywistość, „wirtualne światy”, „sztuczna rzeczywistość”, „sztuczne światy”, „cyfrowa rzeczywistość” oraz „cyfrowe światy” do opisania sposobów wykraczania poza granice realności. W tym najbardziej ogólnym sensie nie używam natomiast sformułowania Augumented Reality (Rzeczywistość

\section{Wprowadzenie}

Rozszerzona) oraz Virtual Reality (Rzeczywistość Wirtualna), traktując je jako konkretne technologie, służące do kreacji sztucznych światów i wpływające na zanurzenie się użytkownika w cyfrowej rzeczywistości.

[2] G.C. Burdea, P. Coiffet, Virtual Reality Technology, New Jersey 2003, s. 4. 
zdolność do identyfikowania się ze swoim awatarem funkcjonującym w przestrzeni cyfrowej.

Za pierwszy eksperyment dotyczący kreacji cyfrowych światów uznaje się doświadczenie Mortona Heiliga wykonane w roku 1960, które Piotr Sitarski określa mianem „prahistorii rzeczywistości wirtualnej"[3]. Polegało ono na umiejscowieniu panoramicznych ekranów w specjalnej kapsule, w której pokazywano obrazy imitujące rzeczywistość. Instalacja Heiliga dała początek eksperymentom tego rodzaju; należy tu wspomnieć o hełmie wykorzystującym ideę panoramicznych ekranów, skonstruowanym przez Ivana Sutherlanda już osiem lat później. Doświadczenia w tym zakresie okazały się jednak na tyle kosztowne, że mogło sobie na nie pozwolić jedynie wojsko. Taki stan rzeczy trwał do połowy lat osiemdziesiątych, kiedy to eksperymenty z zakresu kreacji wirtualnej rzeczywistości zaczęły funkcjonować w obiegu publicznym[4].

Bez wątpienia na ten stan rzeczy miał wpływ rozwój technologii, a zwłaszcza powstanie i upowszechnienie się komputerów osobistych. Od tej pory cyfrowe światy percypowane były w domowym zaciszu na ekranie monitorów. Co istotne, kreowanie wirtualnych przedstawień, rozszerzających granice poznania oraz unaoczniających marzenia, wizje oraz wyobrażenia, od końca lat siedemdziesiątych dokonywało się również $\mathrm{w}$ grach wideo[5]. W dyskusji na temat ontologii przedstawień niefikcjonalnych należało brać więc pod uwagę coraz prężniej rozwijający się przemysł digitalnej rozrywki, która poprzez swój całkowicie cyfrowy charakter, a co za tym idzie - odmienny typ referencji w stosunku do przedstawień kinematograficznych, zaczęła wieść prym w uobecnianiu sztucznej rzeczywistości.

Analizując status cyfrowych światów, Roman Konik wskazuje, że „wirtualność zniosła dystynkcję między strefą realis i virtualis, między prawdą a pozorem [...]” i dodaje dalej, iż „wirtualność dąży do immersyjności, do zatarcia różnicy między światem rzeczywistym a reprezentacją wirtualną" [6]. Rozwój technologiczny, który dokonuje się obecnie, umożliwia realizowanie powyższych założeń; rzeczywistość staje się przedmiotem symulacji, a charakter wirtualnych światów, związany z ich interaktywnością w grach i przekazach elektronicznych, buduje poczucie immersji, rozumianej jako zanurzenie się użytkowników w przestrzeń cyfrową[7]. Obecny poziom techniki pozwala na kreowanie przedstawień, które w kompleksowy sposób imitują rzeczy-

[3] P. Sitarski, Rozmowa z cyfrowym cieniem. Model komunikacyjny rzeczywistości wirtualnej, Kraków 2002, s. 19.

[4] R. Konik, Wirtualność jako rehabilitacja iluzji, „Diametros” 2009, nr 21, wrzesień, s. 78.

[5] W. Siwak, Matrix i pót-Matrix czyli rzeczywistość wirtualna i rzeczywistość rozszerzona jako wyzwania dla tożsamości, kultury, sztuki i edukacji, „Rocznik Naukowy Kujawsko-Pomorskiej Szkoły Wyższej w Bydgoszczy. Transdyscyplinarne Studia o Kulturze

(i) Edukacji" 2016, 11, s. 356.

[6] R. Konik, op.cit., s. 84.

[7] O immersji jako czynniku definiującym poetykę gier na gruncie polskim pisali między innymi: Sitarski (Rozmowa z cyfrowym cieniem. Model komunikacyjny rzeczywistości wirtualnej, 2002), K. Prajzner (Tekst jako świat i gra. Modele narracyjności w kulturze wspótczesnej, 2009) oraz P. Kubiński (Gry wideo. 
wistość. Jedną z technologii, naśladujących realność staje się fotogrametria. W niniejszym artykule dokonam jej charakterystyki, wskazując, w jaki sposób cyfrowe światy zbliżają się do rzeczywistości. Trzon pracy będzie stanowiła analiza gry digitalnej Zaginięcie Ethana Cartera (The Vanishing of Ethan Carter, The Astronauts, 2015) - jej twórcy zdecydowali się zastosować fotogrametrię do oddania rozległych przestrzeni, w których porusza się prowadzony przez użytkownika awatar. Analiza produkcji pozwoli zbadać hipotezę, że zacieranie się granic między fikcją i rzeczywistością służy pogłębieniu immersji gracza. Jednocześnie wskażę, że takie rozwiązanie nie tylko tworzy wiarygodną iluzję rzeczywistości, angażując użytkownika w fikcję, ale również istotnie wpływa na poetykę i narrację gry.

Yves Egels oraz Michel Kasser w książce Digital Photogrammetry definiują fotogrametrię jako „technikę pomiarów umożliwiającą kreowanie trójwymiarowej przestrzeni za pośrednictwem dwuwymiarowych fotografii” [8]. Andrew Hamilton uzupełnia tę charakterystykę: „fotogrametria to w dużym skrócie przekształcanie nieruchomych obrazów w trójwymiarowe siatki wysokiej rozdzielczości. Można to zrobić na kilka sposobów, ale wszystkie wymagają wykonania zdjęć rzeczywistego obiektu i poddania ich obróbce przy pomocy specjalistycznego oprogramowania"[9]. Warto w tym kontekście podkreślić, iż nie jest to jedyna technologia umożliwiająca oddawanie realnych kształtów przedmiotów - innym rozwiązaniem, służącym do tego samego celu, staje się skanowanie $3 \mathrm{D}$, w którym pomiary dokonuje się skanerem opisującym dany obiekt za pomocą siatki współrzędnych oraz opcjonalnie określającym kolor jego powierzchni[10]. Sprzęt fotogrametryczny jest łatwiejszy w obsłudze niż skaner 3D i zapewnia dokładne odwzorowanie nie tylko kształtów, ale również barwy oraz faktury elementów otoczenia.

Skanowanie $3 \mathrm{D}$ oraz fotogrametria przypominają w swej istocie technologię motion-capture, polegającą na przechwytywaniu ruchów aktorów, zamiast programowania ich wyłącznie cyfrowo, a następnie zapisywaniu na komputerze, dzięki czemu w grze można oddać wiarygodne modele postaci[11]. Jakkolwiek motion-capture stało się istotnym przełomem w prezentowaniu cyfrowych przedstawień ludzi i jest regularnie wykorzystywane we współczesnych produkcjach, to nie rozwią-

Zarys poetyki, 2016). Istotny wpływ na polskie teorie dotyczące immersji miały wcześniejsze opracowania anglojęzyczne, w tym: M. Heima (The Metaphysics of Virtual Reality, 1993), M.-L. Ryan (Narrative as Virtual Reality. Immersion and Interactivity in Literature and Electronic Media, 2001) czy O. Grau (Virtual Art. From Illusion to Immersion, 2003).

[8] Y. Egels, M. Kasser, Digital Photogrammetry, London 2002, s. 2, tłum. własne.

[9] Jak przy pomocy fotogrametrii uchwyciliśmy każdy najmniejszy szczegót na potrzeby „Star Wars: Battle-

\section{Fotogrametria w grach cyfrowych}

front”, 2015, <http://starwars.ea.com/pl_PL/starwars/ battlefront/news/how-we-used-photogrammetry-pl> [dostęp: 17.03.2017].

[10] M. Strzyżewski, Fotogrametria to kolejny rewolucyjny skok $w$ rozwoju gier wideo?, 2016, <http://gry. onet.pl/artykuly/fotogrametria-to-kolejny-rewolucyjny-skok-w-rozwoju-gier-wideo/kv95qh> [dostęp: 20.02.2017].

[11] A. Menache, Understanding Motion Capture for Computer Animation and Video Games, San Diego 2000, s. 1. 
zało kwestii odwzorowania środowiska. Nie ulega wątpliwości, że wraz $\mathrm{z}$ rozwojem technologicznym tekstury tła $\mathrm{w}$ grach digitalnych stawały się coraz doskonalsze, czego dowodzą zrealizowane w odstępie kilku lat kolejne części tych samych produkcji, jak choćby trylogia Wiedźmin (2007-2015, CD Projekt Red). Twórcy gier wideo wciąż jednak poszukują rozwiązań umożliwiających kreowanie realistycznego środowiska. Jednym $\mathrm{z}$ nich okazało się wykorzystanie opisywanej technologii.

Źródeł fotogrametrii można dopatrzeć się już w wieku XV, kiedy to za sprawą działalności Leonarda da Vinci rozpowszechniła się znana od starożytności camera obscura - prosty przyrząd umożliwiający wiarygodne imitowanie wyglądów rzeczywistych przestrzeni oraz obiektów. Naturalnym przedłużeniem tego wynalazku stało się wykorzystanie w latach dziewięćdziesiątych analogowego sprzętu fotograficznego do oddania kształtów i odległości między obiektami. Jak wskazuje Wilfried Linder, zdjęcia tworzono wtedy za pomocą nieporęcznej i skomplikowanej aparatury, co sprawiało, że tylko profesjonalni fotografowie mogli ją obsługiwać[12]. Dopiero dzięki cyfryzacji fotogrametria uzyskała znany współcześnie kształt. Początkowo służyła do odtwarzania powierzchni, wielkości oraz położenia obiektów w geometrii, kartografii oraz medycynie, jednak fakt, iż sprzęt uzyskiwał coraz mniejsze rozmiary, stał się tańszy i łatwiejszy w obsłudze, sprawił, że zaczęli go wykorzystywać również twórcy gier wideo[13].

Dan Ablan, autor publikacji Digital Photography for $3 D$ Imaging and Animation, wskazuje, iż obecnie proces fotogrametrycznego oddawania rzeczywistości przebiega następująco:

1. Fotografowanie wybranego, rzeczywistego obszaru pod różnymi kątami.

2. Zaimportowanie i retusz zdjęć cyfrowych.

3. Skalowanie zdjęć.

4. Budowanie geometrycznych kształtów, bazując na zaimportowanych zdjęciach.

5. Zastosowanie zdjęć cyfrowych jako tekstur.

6. Eksportowanie otrzymanego modelu do programu, który przetworzy go $\mathrm{w}$ model trójwymiarowy[14].

Trójwymiarowe obiekty, które użytkownik percypuje, eksplorując wirtualną przestrzeń gry za pośrednictwem awatara, są więc cyfrowym odwzorowaniem rzeczywistych, uprzednio sfotografowanych, obszarów. Co więcej, dzięki metodzie fotogrametrii twórcy gier nie tylko mogą oddać dokładną wielkość, kształt i fakturę otoczenia oraz znajdujących się w nim obiektów, ale również odwzorować odległości między nimi. Dzięki temu potrafią imitować wygląd różnorodnych plenerów, zarówno aglomeracji miejskich, jak i kompleksów leśnych, w całej ich złożoności oraz różnorodności.

Gra cyfrowa, tworzona przy wykorzystaniu techniki fotogrametrii, oferuje więc realistyczną grafikę - w ten sposób fikcjonalny świat

[12] W. Linder, Digital Photogrammetry: A Practical Course, Düsseldorf 2009, s. 7 .

[13] Ibidem.
[14] D. Ablan, Digital Photography for 3 D Imaging and Animation, Indianapolis 2007, s. 210, tłum. własne. 
naśladuje świat niefikcjonalny; cyfrowa rzeczywistość imituje realność. Produkcje zrealizowane na silniku Unreal Engine 4, który umożliwia zastosowanie metody fotogrametrii i zaimplementowanie wcześniej sfotografowanych obiektów na potrzeby środowiska gry[15], są fotorealistyczne. Mimo iż prezentują całkowicie fikcyjną historię, a nawet tak jak w przypadku produkcji Star Wars: Battlefront (2015, Electronic Arts) - przenoszą użytkownika do fikcyjnych światów, zbliżają świat gry do rzeczywistości poprzez jej kopiowanie. Dla przykładu, na wygląd fikcyjnej planety Sullust złożyły się w Battlefront zdjęcia islandzkiej natury, z kolei tereny księżyca Endor zostały zaprojektowane na podstawie fotografii kanadyjskich lasów, pełnych strzelistych sekwoi. Twórcy gry, podróżując po kontynentach, fotografowali wybrane kompleksy leśne, by za ich pomocą oddać różnorodność przestrzeni w świecie Gwiezdnych wojen[16]. Dzięki takiemu rozwiązaniu produkcja nie tylko zachwyca zróżnicowaniem otoczenia, ale również wiarygodnością świata przedstawionego. Podobny cel przyświecał autorom Zaginięcia Ethana Cartera, a fotografie otoczenia, które następnie posłużyło do konstrukcji przestrzeni gry, wykonano w Karkonoszach. W poniższym podrozdziale wykażę, w jaki sposób wykorzystanie technologii fotogrametrii wpłynęło na poetykę i narrację analizowanego tytułu.

Produkcja zrealizowana przez polskie studio The Astronauts, na silniku Unreal Engine 4, klasyfikowana jest na branżowych portalach

Analiza Zaginięcia Ethana Cartera internetowych jako gra przygodowa[17]. Sami twórcy wystrzegają się jednak tego genologicznego określenia, opisując Zaginięcie Ethana Cartera słowami: „pierwszoosobowa gra tajemnic, skoncentrowana na eksploracji i odkrywaniu"[18]. Można przypuszczać, iż takie podejście wynika $\mathrm{z}$ faktu, że określenia gatunkowe produkcji elektronicznych mają charakter dużo bardziej pragmatyczny niż w przypadku filmu. Dzieje się tak, gdyż dominującą tendencją w klasyfikacji gier staje się nie warstwa estetyczna, narracyjna czy dramaturgiczna, ale właściwy dla konkretnych produkcji gameplay[19]. Jednocześnie jednak taka charakterystyka wynika ze specyfiki rozgrywki. Jeszcze przed rozpoczęciem jej właściwej części na ekranie pojawia się biały napis na czarnym tle, informujący użytkownika, iż: „Niniejsza gra jest podróżą bez

[15] M. Zhang, These Aren't Photos - They're Virtual Shots in a Video Game Engine, 2016, <https://petapixel.com/2016/03/29/arent-photos-theyre-virtual-shots-video-game-engine/> [dostęp: 17.03.2017]. [16] Jak przy pomocy fotogrametrii uchwyciliśmy każdy najmniejszy szczegół na potrzeby „Star Wars:

Battlefront", <http://starwars.ea.com/pl_PL/starwars/ battlefront/news/how-we-used-photogrammetry-pl> [dostęp: 17.03.2017].

[17] Z taką genologiczną klasyfikacją można się spotkać zarówno na rodzimych (www.gry-online.pl), jak i anglojęzycznych (www.pcgamer.com) stronach klasyfikujących gry wideo.
[18] Takie określenie widnieje na oficjalnej stronie internetowej twórców (ethancartergame.com) i w oryginale brzmi: "The Vanishing of Ethan Carter is a first-person mystery game focused on exploration and discovery". Tłum. własne.

[19] T.H. Apperley, Genre and Game Studies: Toward a Critical Approach to Video Game Genres, 2006, s. 7. <http://www.academia.edu/385966/Genre_and_ Game_Studies_Toward_a_Critical_Approach_to_Video_Game_Genres> [dostęp: 5.12.2016]. 
przewodnika”. Z jednej strony pełni on funkcję ograniczonego prologu, a $\mathrm{z}$ drugiej ma charakter autoreferencyjny, zwiastując, że produkcja będzie wymagała samodzielności gracza i pozbawiona jest właściwego dla gier przygodowych komentarza, pomagającego opanować jej zasady.

Fabuła Zaginięcia Ethana Cartera skupia się na odnalezieniu tytułowego chłopca, mieszkańca opustoszałego miasteczka Red Creek Valley, który zniknął w tajemniczych okolicznościach, wcześniej nieopatrznie wywołując tajemnicze moce. Gracz wciela się w prywatnego detektywa Paula Prospero, zatrudnianego do rozwiązywania spraw nietypowych, wymykających się racjonalnemu poznaniu. Co istotne, obok rozwiniętych zdolności dedukcyjnych awatar ma również umiejętność przekraczania granicy dzielącej świat realny od paranormalnego. Prospero nie tylko potrafi odczytywać przeszłość, ewokując duchy osób, które brały udział w wydarzeniach rozgrywających się $\mathrm{w}$ miasteczku, ale również wkraczać do rzeczywistości fantazji, wykreowanej w umyśle obdarzonego wyobraźnią Ethana. Napięcie między światem realnym oraz paranormalnym, bezustannie podkreślane w analizowanej produkcji, właściwe jest dla horroru. W konwencji grozy pierwiastek nadnaturalny wkracza do normalnie funkcjonującej rzeczywistości, zmuszając protagonistów do konfrontowania się z nim i w ten sposób wywołując w widzach poczucie strachu[20]. Twórcy podkreślają tę gatunkową proweniencję również na poziomie mechaniki rozgrywki.

Już w pierwszych minutach rozgrywki okazuje się, że gra nie tylko nie przewiduje systemu podpowiedzi, pozwalającego zorientować się w mechanice produkcji, ale również ogranicza interfejs do absolutnego minimum. Pod pojęciem „interfejs” rozumiem sposób komunikowania między systemem a użytkownikiem, mający charakter graficzny lub tekstowy. Dzięki interfejsowi gracz zdobywa informacje na temat istotnych aspektów rozgrywki (na przykład wie, jaką bronią dysponuje awatar, ile zostało mu naboi, jaki jest stan jego zdrowia), a także nakłaniany jest do podjęcia konkretnych rozwiązań (wymiana amunicji, uleczenie postaci). Tę drugą funkcję interfejsu, mającą za zadanie przekonać do zainicjowania określonego działania, Piotr Kubiński określa mianem impresyjnej[21]. W analizowanej produkcji interfejs ma charakter ograniczony: użytkownik nie ma dostępu do ekwipunku postaci, mapy świata przedstawionego ani notatek, które mogłyby podpowiedzieć, w jaki sposób wykonywać kolejne zagadki logiczne. Okno interfejsu pojawia się wyłącznie wtedy, kiedy awatar wchodzi w interakcję z przedmiotem - wówczas za pomocą kontrolera gracz może dany element obrócić bądź przybliżyć. Wokół interaktywnych przedmiotów ukazują się również napisy określające nazwę elementów otoczenia (np. drezyna, lampa olejna, kilof), wskazujące, że są one potrzebne do wykonania zadania. W żaden sposób nie tłumaczą

[20] Noël Carroll określa reakcję emocjonalną wywoływaną przez horrory mianem art-grozy (Filozofia horroru albo paradoksy uczuć, tłum. M. Przylipiak, Gdańsk 2004, s. 31).
[21] P. Kubiński, Gry wideo. Zarys poetyki, Kraków 2016, s. 165. 
jednak, co z danym rekwizytem należy uczynić ani jakie jest jego przeznaczenie - o tym, w toku rozgrywki, musi zadecydować użytkownik. Takie rozwiązanie sprawia, iż Zaginięciu Ethana Cartera bliżej do produkcji logicznych niż przygodowych, gdyż, aby z sukcesem ukończyć historię, należy rozwiązać sekwencje zadań o charakterze logicznym[22]. Wpływa również na budowanie poczucia niepokoju, wynikającego z niewiedzy o przeznaczeniu poszczególnych przedmiotów.

Wszystkie monologi głównego bohatera wypowiadane są z offu, co wynika z przyjęcia perspektywy pierwszoosobowej, sprawiającej, iż użytkownik nie widzi awatara. Kamera znajduje się na poziomie jego oczu, a gracz steruje ruchami Prospero, percypując świat z punktu widzenia postaci. Warto $\mathrm{w}$ tym kontekście podkreślić, iż działania bohatera, podobnie jak interfejs rozgrywki, są ograniczone. Użytkownik, wchodząc w interakcję z systemem gry, może obracać głowę awatara, umożliwiając mu oglądanie przestrzeni, a także chodzić oraz schylać się, jednak twórcy nie przewidzieli możliwości skakania i biegania. Fakt, iż bohater nie dysponuje ekwipunkiem, sprawia, iż nie może on dobywać broni czy wyjmować innych elementów wyposażenia. Jakkolwiek analizowana produkcja na poziomie mechaniki nawiązuje więc do konwencji first person shooters, to jednocześnie ją reinterpretuje przez wprowadzenie wymienionych ograniczeń. Takie rozwiązanie wywołuje również szereg pytań sprawiających, że Prospero jawi się jako postać niejasna: dlaczego przybył do miasteczka nieprzygotowany, skoro Ethan Carter przestrzegał w swoich listach przed niebezpieczeństwem? oraz w jaki sposób zamierza konfrontować się z siłami, które opanowały Red Creek Valley? Powyższe wątpliwości wzmagają niepokój, intensyfikowany przez świadomość, że nieprzygotowany bohater jest jednocześnie awatarem gracza, którego użytkownik musi z sukcesem przeprowadzić przez niebezpieczeństwo, by ukończyć grę.

Jednocześnie ograniczony interfejs, zastosowanie perspektywy pierwszoosobowej oraz brak ekwipunku istotnie wpływają na sposób, w jaki użytkownik postrzega i interpretuje fotorealistyczny świat gry. Gracz percypuje rzeczywistość niezmąconą dystraktorami, takimi jak interfejs graficzny czy wygląd awatara w kadrze - to, co widzi, to z pieczołowitością oddany wygląd rzeczywistych przestrzeni. Jak zostało wspomniane, zdjęcia, które posłużyły za prototyp lokacji, są fotografiami wybranych miejsc w Karkonoszach. Na wygląd świata składają się punkty charakterystyczne, takie jak: droga z nieużywanymi torami, dwa domy i prowadzący do nich most, kościół z cmentarzem, kopalnia oraz spalona posiadłość nad malowniczo położonym górskim jeziorem. Miej-

[22] Nie oznacza to, iż gry przygodowe w ogóle pozbawione są zadań o charakterze logicznym, gdyż historia rozwoju gatunku pokazuje, iż jest odwrotnie, choćby wspomnieć gry, pochodzące z lat dziewięćdziesiątych, takie jak: Discworld (1995, Perfect 10 Productions), Tomb Rider (1996, Core Design) czy Larry 7: Miłość na fali (1997, Sierra Entertainment).
Element logiczny w grach przygodowych jest tylko dodatkiem do rozgrywki, skupionej na eksplorowaniu świata. Zagadki logiczne mają różne poziomy trudności, jednak w założeniu twórców nie mogą one odrywać gracza od toku fabuły, toteż poziom ich skomplikowania powinien być ograniczony. 
sca połączone zostały ścieżkami prowadzącymi przez kompleks leśny. Znacząca część Zaginięcia Ethana Cartera rozgrywa się więc w plenerach, a celem twórców stało się wykorzystanie technologii fotogrametrii do jak najwierniejszego odwzorowania przyrody, w całej jej różnorodności i złożoności[23]. Zabieg ten miał wpływać na jak najpełniejsze zanurzenie użytkownika w cyfrowy świat. Jak wskazuje Adam Bryla, grafik gry:

Kiedy nie podążasz za wytycznymi, dawanymi przez matkę naturę, zawsze pominiesz istotne szczegóły. Dlatego że wydają się one pozornie nieważne. Ignorowanie porządku natury prowadzi jednak do błędów, takich jak nieprawdopodobne wielkości obiektów. [...] Kiedy zmienia się wielkość elementów otoczenia, przedstawienie traci wiarygodność, na której nam zależało[24].

Fotogrametryczne oddawanie wyglądu przestrzeni nie tylko pozwoliło twórcom na proporcjonalne odtworzenie skali obiektów, ale również na odwzorowanie ich w taki sposób, w jaki jawią się w rzeczywistości - zarówno jeśli chodzi o położenie większych elementów natury, takich jak drzewa, jak i mniejszych - takich jak liście, które z nich spadły.

Warto w tym kontekście zwrócić uwagę na fakt, iż fotogrametria umożliwiła również oddanie elementów przestrzeni w całej ich złożoności - tekstury obiektów są niezwykle realistyczne i pełne detali. Obserwując pień drzewa, użytkownik może dostrzec jego sęki, natomiast spoglądając na głaz - jego chropowatą, nierówną powierzchnię. Ponadto, obiekty w świecie gry współistnieją ze sobą dzięki imitowaniu światłocienia i ruchu pod wpływem wiatru. Konstrukcja przestrzeni związana jest ze sposobem jej eksplorowania przez awatara. Paul Prospero spaceruje po drogach powoli i niespiesznie, przyglądając się elementom otoczenia. Takie rozwiązanie oddaje detektywistyczny charakter fabuły, jednak sprawia również, iż przejście od jednego punktu do drugiego zajmuje relatywnie dużo czasu. Dla przykładu, żeby przejść z kościoła do kopalni, należy poświęcić kilkanaście minut, idąc krętą ścieżką, przebiegającą przez łąkę i tunel. Autorzy zrezygnowali więc z elips montażowych, które skróciłyby czas wędrówki między dwoma punktami. Powyższa decyzja niejako wymusza na użytkowniku obserwowanie fotorealistycznego świata w całej jego złożoności i dokładności odwzorowania, przez co nadaje Zaginięciu Ethana Cartera charakter symulacyjny.

Symulatory wideo dążą do odwzorowania rzeczywistych aktywności, takich jak na przykład przemierzanie atrakcyjnych wizualnie terenów. Jak wskazuje Marzena Falkowska, w tego rodzaju produkcjach chodzenie staje się świadomie wybranym środkiem ekspresji, dzięki któremu rozwija się fabuła. Dodaje również, iż „symulatory chodzenia wywołują niepokój przez budowanie nastroju izolacji, poczucia bycia obserwowanym [...]"[25]. Użytkownik, prowadząc awatara po fotore-

[23] A. Bryla, How we approached ${ }_{3} D$ foliage in The Vanishing of Ethan Carter, 2014, <http://www. theastronauts.com/2014/02/approached-3d-foliage-vanishing-ethan-carter/> [dostęp: 15.03.2017].
[24] Ibidem.

[25] M. Falkowska, Uroki szwendania, 2013, <http:// www.dwutygodnik.com/artykul/6463-uroki-szwendania.html> [dostęp: 15.03.2017]. 
alistycznym miasteczku Red Creek Valley, niemal cały czas pozostaje w izolacji - jego jedynym towarzystwem staje się wszechotaczająca przyroda, a momenty, gdy spotyka innych, należą do sfery nierzeczywistej. Kiedy Prospero przekracza granicę między światem realnym a paranormalnym, barwy zmieniają się na monochromatyczne i zmniejsza się natężenie odgłosów natury. Żaden $z$ bohaterów, obecnych w retrospektywnych sekwencjach, nie zwraca uwagi na awatara. Podkreśla to jego izolację oraz niedopasowanie względem mieszkańców miasteczka.

Prowadzony przez użytkownika awatar, błąkając się po lasach Red Creek Valley, jest więc wyobcowany, a źródło tej samotności można odkryć jedynie, poprzez przemierzanie odległości dzielących postać od kolejnych miejsc charakterystycznych. W tym sensie wędrując, gracz odkrywa fabułę produkcji, gdyż poszczególne elementy zagadki wyjaśniane są w czasie eksploracji świata. Jednocześnie, dzięki fotorealistycznej grafice, wyobcowanie postaci nie przekłada się na zdystansowanie użytkownika. Zastosowanie technologii fotogrametrii, urzeczywistniającej świat gry poprzez swoje referencje do rzeczywistości, wpływa na immersję. Wynika to $\mathrm{z}$ faktu, iż gracz rozpoznaje przestrzenie lub elementy otoczenia znane $z$ realności i potrafi nadać im znaczenie. Dzięki temu rzeczywistość gry przestaje być abstrakcyjna, a staje się oswojona, odwołuje się do rzeczywistych doświadczeń użytkownika.

W świecie, w którym awatar z łatwością (i często bez zapowiedzi) przekracza granicę między realnością a niesamowitością, który jawi się jako niepokojący i niebezpieczny, a ponadto przepełniony jest trudnymi do rozwiązania zagadkami, natura zdaje się jedynym pewnym punktem odniesienia. Dokładność odwzorowania przyrody, niemal jej namacalność sprawia, że gracz - mimo iż pozbawiony interfejsu, historii awatara czy kontekstu zaginięcia chłopca - ma poczucie zakorzenienia w fikcyjnym świecie. Poszukując Ethana Cartera i tropiąc przyczyny śmierci członków jego rodziny, Paul Prospero odwiedza coraz bardziej nieprawdopodobne światy, takie jak przestrzeń kosmiczna czy podwodna kraina zamieszkana przez potwora przypominającego Cthulhu (rozwiązania fabularne prezentowane w grze nawiązują do prozy H.P. Lovecrafta). Ich różnorodność wynika $\mathrm{z}$ faktu, iż detektyw wizualizuje sobie niepokojące opowiadania Ethana, które znajduje zapisane w określonych punktach lokacji. W zestawieniu z obrazami dziecięcej wyobraźni, to właśnie świat wszechotaczającej natury wydaje się jedynym pewnym punktem odniesienia, a Red Creek Valley - prawdziwą rzeczywistością.

Pieczołowita imitacja realności w Zaginięcu Ethana Cartera okazuje się jednak oszustwem, rodzajem pułapki zastawionej na gracza. W czasie rozwiązywania zagadki zniknięcia chłopca użytkownik dowiaduje się, iż nieświadomie przyzwał on mroczne siły, które powoli opętują mieszkańców miasteczka i rozkazują im zabić Ethana. W toku rozwoju fabuły, a zwłaszcza w jej punkcie kulminacyjnym, kiedy w kopalni Red Creek Valley pojawia się przejście do innego wymiaru, historia staje się coraz bardziej nieprawdopodobna, przypominając fantastyczne opowiadania Cartera. W zakończeniu gry, po rozwiąza- 
niu wszystkich zagadek oraz prześledzeniu tropów, pojawia się krótka sekwencja retrospektywna w formie nieinteraktywnej cut-scenes[26]. W scenie, pełniącej jednocześnie funkcję epilogu, wyjaśnia się, iż Paul Prospero był tylko owocem imaginacji Ethana Cartera, a chłopiec w wyniku nieszczęśliwego zbiegu okoliczności zginął, zatrzasnąwszy się $\mathrm{w}$ piwnicy płonącego domu. $\mathrm{W}$ tym sensie fotogrametryczna grafika została wykorzystana po to, by grać z przyzwyczajeniami odbiorczymi użytkownika: świat, który wydawał się realny, okazuje się największą ułudą. Nie tylko awatar gracza na poziomie fabularnym jest wyimaginowanym bytem, ale również fotorealistyczna przestrzeń, którą eksplorował, pozostaje tylko częścią wyobrażeń chłopca. Fotogrametrycznie odwzorowane lokacje nie mają więc żadnego związku z rzeczywistością; ich referencja do prawdziwego świata zostaje całkowicie zniesiona. Zastosowanie takiego rozwiązania ma charakter autorefleksyjny - twórcy wskazują, że to, co jawi się w Zaginięciu Ethana Cartera jako realne, jest - w swojej istocie - kolejnym etapem wirtualności; nic, co pojawia się w grze, rzeczywiste być nie może, bo nie taka jest natura przedstawień wideo, które, na poziomie ontologicznym, są całkowicie sztuczne.

\section{Podsumowanie}

Iluzja rzeczywistości, budowana w produkcji studia The Astronauts, zostaje więc w toku rozwoju fabuły podważona - aby mogło się to zakończyć sukcesem, użytkownik musi uwierzyć, że świat, który przemierza za pośrednictwem awatara, jest prawdziwy. Służy temu szczegółowe odwzorowanie przestrzeni wykorzystujące fotografie karkonoskich gór, które tworzy poczucie realności: w tym sensie gra imituje rzeczywistość. Wykorzystanie fotogrametrii wpłynęło więc istotnie na poetykę oraz narrację gry. Z jednej strony, naśladuje ona realność, z drugiej jednak - została wykorzystana jako źródło chwytu narracyjnego, obnażającego iluzję świata przedstawionego. Ponadto zastosowanie analizowanej technologii istotnie wpłynęło na poetykę produkcji. Twórcy zdecydowali się ograniczyć interfejs oraz sposoby poruszania się postaci, aby umożliwić użytkownikowi niczym niezmącony ogląd fotorealistycznej rzeczywistości. Gra została zaprojektowana w taki sposób, aby odbiorca kontemplował pieczołowicie odwzorowany świat realny - dlatego też gracz percypuje rzeczywistość z punktu widzenia awatara, a kamera umieszczona jest na wysokości jej oczu. $Z$ tego również powodu opcja biegania nie została zaimplementowana, a Paul Prospero porusza się po przestrzeni niespiesznie.

Zaadaptowane i rozpowszechnione w przemyśle wideo rozwiązania technologiczne, takie jak fotogrametria, skanowanie $3 \mathrm{D}$ czy motion-capture, mają na celu jak najwierniejsze imitowanie rzeczywistości. Zacieranie granicy między wirtualnością a realnością, stanowiące cechę

[26] Cut-scenes, czy też inaczej sceny przerywnikowe, to wplecione w tkankę gry krótkie, nieinteraktywne filmy. Ich celem staje się podsumowanie danego etapu rozgrywki, wprowadzenie nowych wątków lub zbudowanie narracyjnego pomostu między kolejnymi aktami gry (K. Salen, E. Zimmerman, Rules of Play. Game Design Fundamentals, Cambridge, MA, 2003, S. 410$)$. 
współczesnych produkcji elektronicznych, znacząco wpływa na immersję gracza. Wydaje się, iż zanurzenie w cyfrowo wykreowane światy dokonuje się pełniej wtedy, kiedy gra wieloaspektowo i szczegółowo odtwarza realność. Wynika to $z$ faktu, iż fotorealistyczna przestrzeń odwołuje się do wiedzy gracza na temat rzeczywistych miejsc. Rozpoznanie jej sprawia, że staje się zrozumiała i oswojona. W grach starszej generacji, które operowały prostą, dwuwymiarową grafiką, z wyraźnie widocznymi pikselami, przestrzeń była tylko symbolem realności - na przykład przerywana linia w grze Pong (1972, Atari), nakreślona na czarnym tle, symbolizowała siatkę oddzielającą dwie części stołu do ping-ponga. Otoczenie fotogrametryczne przestaje być metaforą, stając się imitacją realnej przestrzeni, a kiedy gracz w tę imitację wierzy i ją akceptuje, pełniej zanurza się w wirtualną rzeczywistość.

Ablan D., Digital Photography for 3D Imaging and Animation, Indianapolis 2007

Apperley T.H., Genre and Game Studies: Toward a Critical Approach to Video Game Genres, 2006, <http://www.academia.edu/385966/Genre_and_Game_Studies_ Toward_a_Critical_Approach_to_Video_Game_Genres> [dostęp: 5.12.2016]

Bryla A., How we approached 3D foliage in The Vanishing of Ethan Carter, 2014, $<$ http://www.theastronauts.com/2014/02/approached-3d-foliage-vanishing-ethan-carter/> [dostęp: 15.03.2017]

Burdea G.C., Coiffer Ph., Virtual Reality Technology, Hoboken, NJ., 2003

Carroll N., Filozofia horroru albo paradoksy uczuć, tłum. M. Przylipiak, Gdańsk 2004

Egels Y., Kasser M., Digital Photogrammetry, London 2002

Falkowska M., Uroki szwendania, 2013, <http://www.dwutygodnik.com/ artykul/6463-uroki-szwendania.html> [dostęp: 15.03.2017]

Jak przy pomocy fotogrametrii uchwyciliśmy każdy najmniejszy szczegót na potrzeby „Star Wars: Battlefront", 2015, <http://starwars.ea.com/pl_PL/starwars/battlefront/news/how-we-used-photogrammetry-pl> [dostęp: 17.03.2017]

Konik R., Wirtualność jako rehabilitacja iluzji, „Diametros” 2009, nr 21, wrzesień

Kubiński P., Gry wideo. Zarys poetyki, Kraków 2016

Linder W., Digital Photogrammetry: A Practical Course, Düsseldorf 2009

Menache A., Understanding Motion Capture for Computer Animation and Video Games, San Diego 2000

Salen K., Zimmerman E., Rules of Play. Game Design Fundamentals, Cambridge, Mass., 2003

Sitarski P., Rozmowa z cyfrowym cieniem. Model komunikacyjny rzeczywistości wirtualnej, Kraków, 2002.

Siwak W., Matrix i pót-Matrix czyli rzeczywistość wirtualna i rzeczywistość rozszerzona jako wyzwania dla tożsamości, kultury, sztuki i edukacji, „Rocznik Naukowy Kujawsko-Pomorskiej Szkoły Wyższej w Bydgoszczy. Transdyscyplinarne Studia o Kulturze (i) Edukacji” 2016, nr 11

Strzyżewski M., Fotogrametria to kolejny rewolucyjny skok w rozwoju gier wideo?, 2016, <http://gry.onet.pl/artykuly/fotogrametria-to-kolejny-rewolucyjny-skok-w-rozwoju-gier-wideo/kv95qh> [dostęp: 15.03.2017]

Zhang M., These Aren't Photos - They're Virtual Shots in a Video Game Engine, 2016, $<$ https://petapixel.com/2016/03/29/arent-photos-theyre-virtual-shots-video-game-engine/> [dostęp: 17.03.2017] 


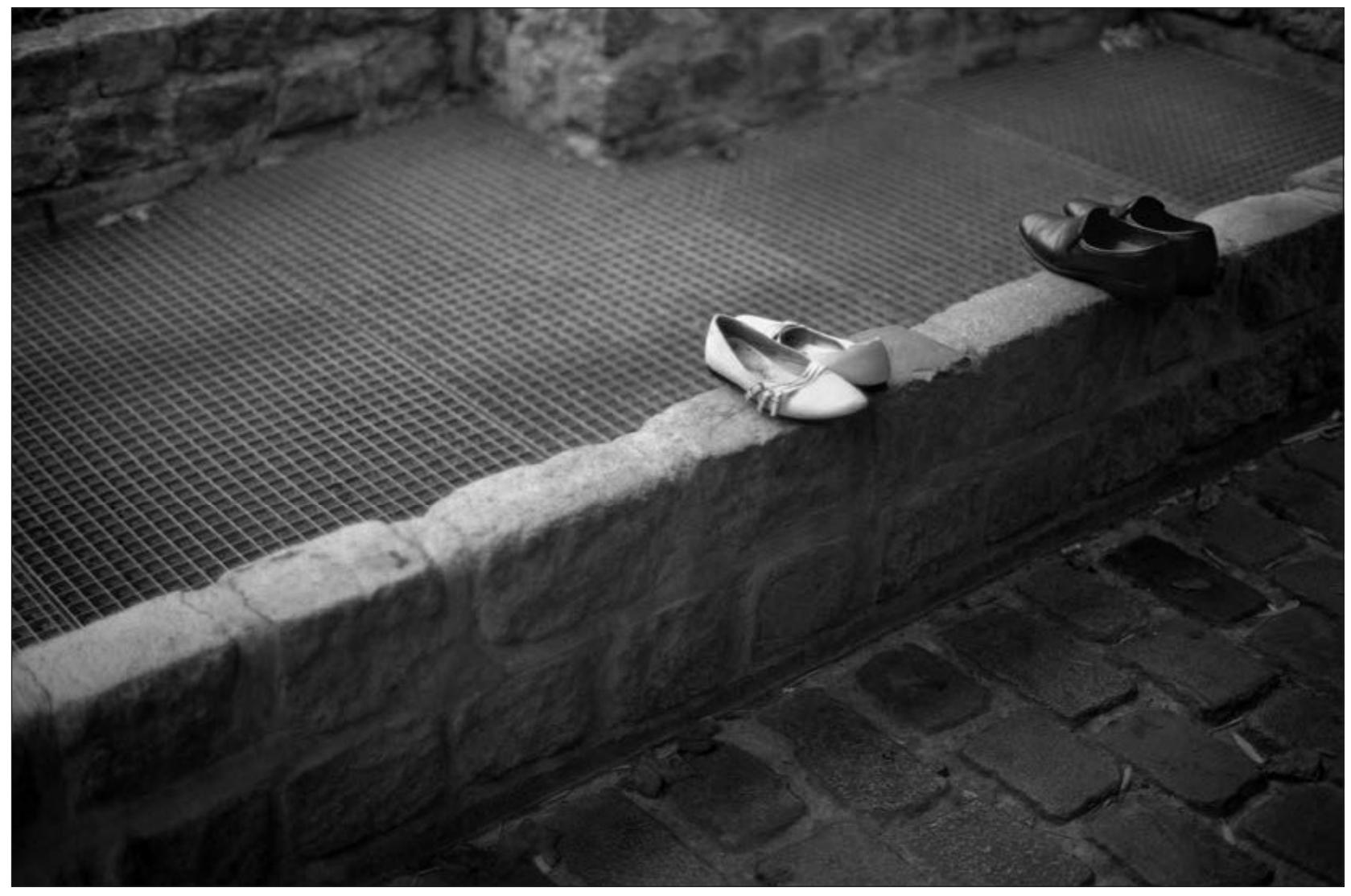

Fot. Sebastian Buttny 